\title{
Varicella-zoster virus
}

meningo-rhombencephalitis presenting as Ramsey Hunt

自

Figure 1 Audiovestibular investigations show a right pan-frequency sensorineural hearing loss (A) and complete canal paresis (B)

A
Supplemental data at www.neurology.org

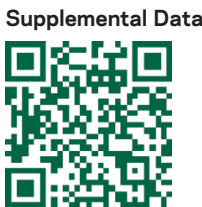

Pure tone audiogram

Air conduction, masked if neccessary
Air conduction, not masked (shadow)

RIGHT

FREQUENCY (Hz)

30006000

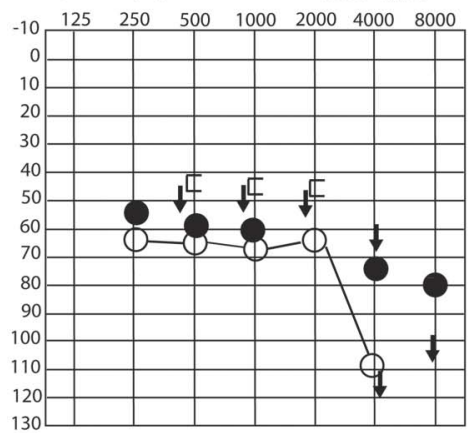

LEFT

FREQUENCY (Hz)

30006000

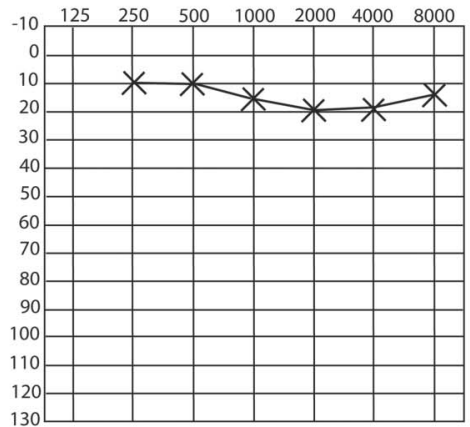

Bithermal caloric irrigation

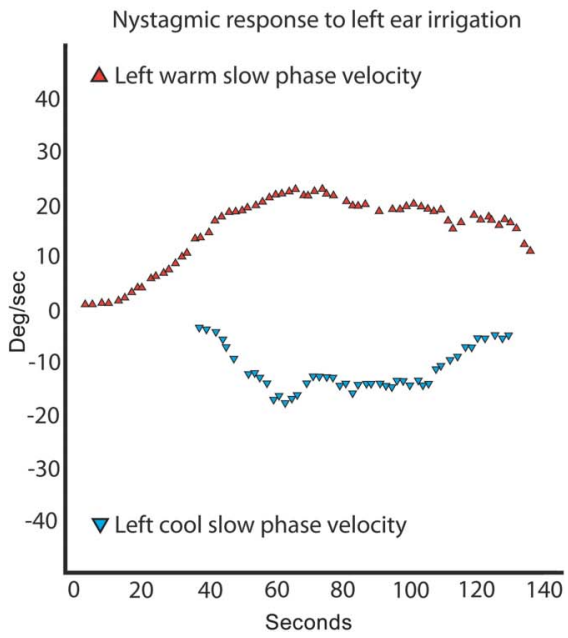

A 45-year-old woman on etanercept for rheumatoid arthritis presented with an acute right Bell palsy and auricular herpetic rash (Ramsey Hunt syndrome). Despite IV acyclovir, she developed headache, vertigo, severe vomiting, and evidence of a right peripheral audiovestibular loss (figure 1, A and B, video 1 on the Neurology ${ }^{\circledR}$ Web site at www.neurology.org). Ongoing symptoms indicated CSF examination, which showed a pleocytosis and positive varicella-zoster PCR, and an MRI that displayed abnormal brainstem signal (figure 2, A and B). Although there was unequivocal peripheral audiovestibular loss, ${ }^{1}$ the persistence of vertigo beyond 3 days is a red flag suggesting central involvement, ${ }^{2}$ here presumably resulting from the known effect of etanercept on impairing leukocyte migration ${ }^{3}$ into the brain. 
Figure 2 Sagittal T2 (A) and coronal flair (B) MRI show high signal in the right rostrolateral medulla extending into the tegmentum of the adjacent pons, and involving the floor of the fourth ventricle (arrows)
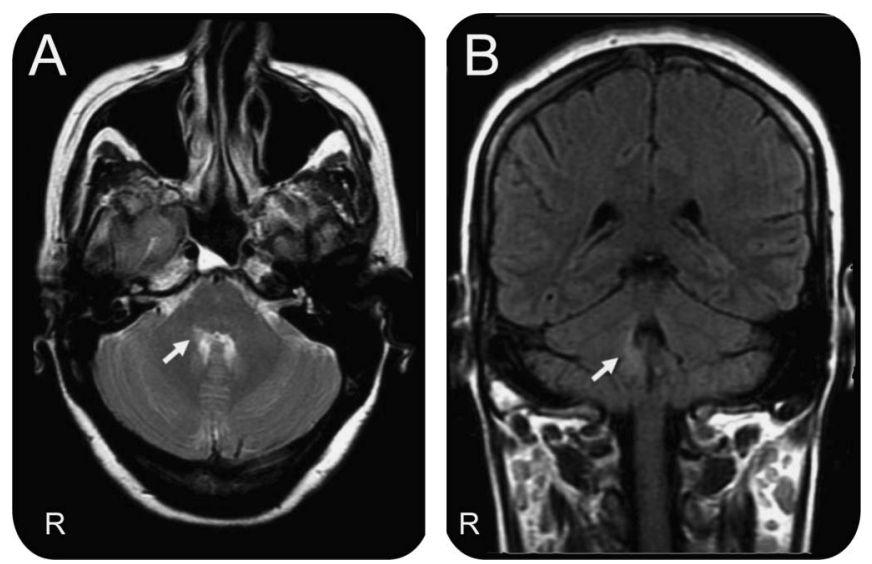

Diego Kaski, MBBS, MRCP, Nicholas Davies, MBBS, MRCP, PhD, Barry M. Seemungal, MBBS, MRCP, PhD, London, UK

Author contributions: D.K. reviewed the clinical case and prepared the manuscript, figures, and video. B.M.S. and N.D. performed the clinical examination, commented critically on the manuscript, and B.M.S. approved its final version.

Acknowledgment: The authors thank Luca Seemungal for video editing.

The authors report no disclosures relevant to the manuscript. Go to Neurology.org for full disclosures.

Correspondence \& reprint requests to Dr. Seemungal: b.seemungal@imperial.ac.uk

1. Abramovich S, Prasher DK. Electrocochleography and brain-stem potentials in Ramsay Hunt syndrome. Arch Otolaryngol Head Neck Surg 1986;112:925-928.

2. Katsarkas A. Vestibular and oculomotor disturbances in pathology of the fourth ventricle. Laryngoscope 1981;91:71-77.

3. Ducharme E, Weinberg JM. Etanercept. Expert Opin Biol Ther 2008;8:491-502.

\section{NeuroImages Are Free at www.neurology.org!}

All Neurology ${ }^{\circledR}$ NeuroImages can now be freely accessed on the Neurology Web site. See them at www.neurology.org, where you can also sign up for journal email alerts and check out other online features, including the Resident \& Fellow section, Neurology: Clinical Practice, and the weekly Neurology Podcasts. 


\title{
Neurology
}

\author{
Varicella-zoster virus meningo-rhombencephalitis presenting as Ramsey Hunt \\ Diego Kaski, Nicholas Davies and Barry M. Seemungal \\ Neurology 2012;79;2291-2292 \\ DOI 10.1212/WNL.0b013e31827689c2
}

This information is current as of December 3, 2012

\section{Updated Information \& Services \\ Supplementary Material \\ References \\ Subspecialty Collections}

Permissions \& Licensing

Reprints including high resolution figures, can be found at: http://n.neurology.org/content/79/23/2291.full

Supplementary material can be found at: http://n.neurology.org/content/suppl/2012/12/02/79.23.2291.DC1

This article cites 3 articles, 0 of which you can access for free at: http://n.neurology.org/content/79/23/2291.full\#ref-list-1

This article, along with others on similar topics, appears in the following collection(s):

\section{All Education}

http://n.neurology.org/cgi/collection/all_education

Vertigo

http://n.neurology.org/cgi/collection/vertigo

Viral infections

http://n.neurology.org/cgi/collection/viral_infections

Information about reproducing this article in parts (figures,tables) or in its entirety can be found online at:

http://www.neurology.org/about/about_the_journal\#permissions

Information about ordering reprints can be found online:

http://n.neurology.org/subscribers/advertise

Neurology ${ }^{\circledR}$ is the official journal of the American Academy of Neurology. Published continuously since 1951, it is now a weekly with 48 issues per year. Copyright (O) 2012 American Academy of Neurology. All rights reserved. Print ISSN: 0028-3878. Online ISSN: 1526-632X.

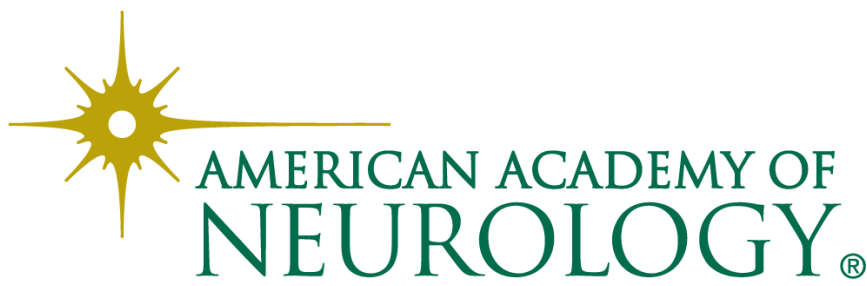

